\title{
Energy Consumption, Environmental Degradation and Growth: A Panel Data Analysis
}

\author{
Sayed Kushairi Sayed Nordin ${ }^{1,2}$ and Siok Kun Sek ${ }^{3}$
}

\section{${ }^{1,3}$ Universiti Sains Malaysia ${ }^{2}$ Universiti Teknikal Malaysia Melaka}

\begin{abstract}
Energy is essential as an input to develop economic, although it could bring negative effect on environmental quality. The relationship between energy consumption, environmental degradation and economic growth have been widely studied, but there is no consistency in the relationship. The objectives of this study are to determine the short-run relationship (one-way or bidirectional) and to reveal the longrun relationship for each pair of variables. The second-generation panel unit root and cointegration test were used in the analysis. Breusch-Pagan LM test suggests that there is a cross-sectional dependency for all the models and integrated of order one, I (1). Cointegration test indicates that economic growth has long-relationship with carbon dioxide and energy consumption in high-income countries. In low-income countries, carbon dioxide has a long-run relationship with energy consumption and economic growth. In the short run, we have evidence of a bidirectional relationship between energy consumption and economic growth in high-income countries but a one-way relationship in low-income countries. Overall, it can be concluded that the three variables are related. This study develops a deeper awareness and understanding of the relationship between the variables in distinct levels of economies.
\end{abstract}

Keywords: energy consumption; $\mathrm{CO} 2$, economic growth

\section{INTRODUCTION}

Energy is important in most aspects of our life. Energy as a non-substitutable resource has been focused on in most countries to stimulate their industrial sector. However, the decrease in environmental quality is a constraint in many countries due to the progress of development. At this phase, investors seeking resources will develop roads, railways, factories, and facilities. This leaves a positive effect on economic growth, but not necessarily to the environment in the long term. Countries with an abundance of resources must have policies on protecting their environment. The high energy consumption not only promotes growth but contributes to the negative effect's environmental quality. The use of vast amounts of coal as an energy source in China causes environmental problems such as sulphur dioxide (SO2) emission, particulate emission (pm) (Qian \& Zhang, 1998), nitrogen oxides (NOx) and carbon dioxide (CO2) emissions. The unsustainable development leads to global warming and climate change, where $\mathrm{CO} 2$ emission is the major contributor to greenhouse gases. China and the United States had reported emitting about half of the total $\mathrm{CO}_{2}$ emissions in 2015. Meanwhile, the IMF's World Economic Outlook Database 2016 revealed that these two countries are the top two economies in the world.

Although the link between energy consumption, environmental degradation and economic growth are explored in many studies, there is no agreement on the relationship. Therefore, this study aims to examine the shortrun relationship (unidirectional or bidirectional) and to reveal the long-run relationship for each pair of variables. To the best of our knowledge, this study is one of the first few attempts to investigate the long-run and the short-run relationship between the variables by comparing the results from high-income and low-income countries using panel data approach. Previous studies were done by Ozturk, Aslan \& Kalyoncu (2010) and Zaman \& Moemen (2017) are different in terms of modelling techniques, variables or countries

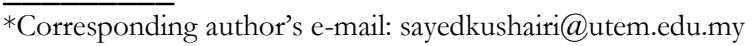


selection in their analysis.

\section{LITERATURE REVIEW}

Environmental Kuznets Curve (EKC) has been referred widely in the environmental-economic literature. EKC describes that the environment degraded will initially increase with respect to economic growth before the direction is reversed. The turning point occurs when countries reach stability in the economy. The relationship between degradation and growth of EKC is represented in inverted-U shaped.

Besides of environmental-economic issues, studies in energy consumption and the relation to economic growth appear as one of the important topics being discussed. Energy consumption is closely related to economic growth by providing a source to industries. Increased in energy consumed will stimulate economic development (Ang, 2007). Furthermore, Biophysical Models of the economy also proposes that energy is the main source of production (Stern, 1999).

Solow's (1956) original growth model states that the economy must reach a stationary phase in which there is no more additional investment needed. This theory argues that technological progress is important to achieve continuing economic growth. In contrast, Dasgupta and Heal (1979) suggest that although the growth is reached efficiently, the degradation to the environment is unavoidable. The current economic growth can be considered as not sustainable as the trade-off effect from production activities (Haywood 1995).

Empirical, there seem to be contradictory outcomes due to the different data used, the selection of countries, as well as the different approach and model used and the time period examined (Ozturk, 2010). In country-level research, most had revealed that the causality is running from energy consumption and economic growth. Bozkurt and Akan (2014) investigated the long-run effect of $\mathrm{CO} 2$ and energy consumption on economic growth in the context of Turkey using panel data from 1960-2010 and revealed that $\mathrm{CO} 2$ emission is inverse to economic growth. As expected, energy consumption has a positive effect on economic growth. Moreover, Ozturk (2010) used panel data from 1971-2005 in three groups of countries. He found that there is no evidence of a strong correlation between these variables in all income groups. For low-income countries, the test showed that there is long-run Granger causality running from GDP to energy consumption while a two-way relationship between these variables was observed in lower and upper-middle-income countries.

Apergis (2009) and Ozcan (2013) examined the relationship betweenCO2, energy consumption and GDP; Apergis (2009) extended Ang (2007) study on panel framework. Using data from 1971-2004 from six Central American countries, they concluded that energy consumption has a positive link with $\mathrm{CO} 2$ emissions, whereas, the real output indicates a quadratic relationship and both energy consumption and economic growth affect the emission in the short-run. A study conducted by Suocheng et. al., (2011) indicated that there is a robust long-term relationship between these three variables.

Ang (2007) confirmed a U-shaped EKC from five Middle East countries, while three countries exhibit an inverted Ushaped curve. In the short-run, there is unidirectional causality from economic growth to energy consumption and the unidirectional causality running from energy consumption and economic growth in $\mathrm{CO}_{2}$ emissions. Researches by Cinar et. al., (2012), Wang et. al., (2011), Wang et al., (2013), Yin et. al., (2015), Saatci and Yasemin (2011) and Cinar (2012). The first empirical study attributed to EKC conducted by Grossman and Krueger (1991) concluded that the advancement of technology and machining would lead to a decrease in pollution once advancement has been achieved. Pala (2016) and Mercan and Karakaya (2015) used a panel approach to study the OECD countries; Pala found that the presence of a long-run relationship between economic growth and energy consumption and a bidirectional causality relationship between these two variables., using data from 1970-2011, Kaka and Zervas (2013) found that the direction of the variables is similar to Bozkurt and Akan (2014) in the short-run. Meanwhile, Karakas (2014) compared the relationship between OECD and non-OECD countries using data from 1990-2011 and reported that both groups of countries have a positive relationship between economic growth and $\mathrm{CO} 2$ emissions.

\section{RESEARCH METHODOLOGY}

Panel data approach is used in this study. Thirty countries were selected and divided into two groups. The countries are:

i. High-income countries: Australia, Austria, Canada, Chile, Denmark, France, Finland, Hong 
Kong, Japan, Netherlands, Norway, New Zealand, Singapore, Spain, United States

ii. Low-income countries: Benin, Bolivia, Cameroon, Egypt, Indonesia, India, Kenya, Sri Lanka, Nepal, Pakistan, Philippines, Sudan, Senegal, Tunisia, Togo

The countries are classified based on GNI per capita, Atlas method (current US\$) from The World Bank. The data used are energy consumption ( $\mathrm{kg}$ of oil equivalent per capita), $\mathrm{CO} 2$ emissions (metric tons per capita) and GDP per capita (current US\$) as the proxies for energy consumption, environmental degradation and growth respectively. The annual data from the year 1971 to 2014were retrieved from World Bank Development Indicators. The data were in natural logarithm for consistency.

The empirical models are given by:

$$
\begin{aligned}
& E C_{i t}=\alpha_{o}+\beta_{1} G D P_{i t}+\beta_{2} C O_{2 i t}+\varepsilon_{i t}(1) \\
& G D P_{i t}=\alpha_{o}+\beta_{1} E C_{i t}+\beta_{2} C O_{2 i t}+\varepsilon_{i t}(2) \\
& C O_{2 i t}=\alpha_{o}+\beta_{1} G D P_{i t}+\beta_{2} E C_{i t}+\varepsilon_{i t}(3)
\end{aligned}
$$

Where EC is the energy consumption, GDP is the gross domestic product and $\mathrm{CO}_{2}$ is the carbon dioxide emissions, $\alpha_{o}$ is a constant term, $\beta_{1}$ and $\beta_{2}$ are parameters to be estimated. The $i$ is the cross-section data for countries, $t$ is the time series data and $\varepsilon$ is the error term.

The analysis part begins with examining the crosssectional dependency in fitting the panel data models. We employed Lagrange Multiplier (LM) developed by BreuschPagan (1980). The LM statistic is given by:

$$
L M=T \sum_{i=1}^{N-1} \sum_{j=i+1}^{N} \hat{\rho}^{2}{ }_{i j}
$$

where $\hat{\rho}_{i j}$ is the sample estimate of the pairwise correlation residuals

$$
\hat{\rho}_{i j}=\frac{\sum_{t=1}^{T} \hat{\mu}_{i t} \hat{\mu}_{i t}}{\left(\sum_{t=1}^{T} \hat{\mu}^{2}{ }_{i t}\right)^{1 / 2}\left(\sum_{t=1}^{T} \hat{\mu}^{2}{ }_{i t}\right)^{1 / 2}}
$$

and $\hat{\mu}^{2}{ }_{i t}$ is the estimate of $\mu_{i t}$.

Secondly, the second-generation unit root test, Pesaran (2003) is used to check the stationarity. The null hypothesis is nonstationary series and the alternative hypothesis is stationary series. If the residuals are not serially correlated, the regression is employed for the $i^{t h}$ country is given by:

$$
\Delta Y_{i t}=\alpha_{i}+\rho_{i} Y_{1, t-1}+c_{i} \bar{Y}_{t-1}+d_{i} \Delta \bar{Y}_{t}+\vartheta_{i t}
$$

where $\bar{Y}_{i t}=\left(\frac{1}{N}\right) \sum_{i=1}^{N} Y_{i t-1}$ and $\Delta \bar{Y}_{i t}=\left(\frac{1}{N}\right) \sum_{i=1}^{N} \Delta Y_{i t}$
If all variables are integrated of the same order, panel cointegration test can be performed to check whether the variables have long-run relationships. This study used the second generation cointegration test, Westerlund (2007). This test is based on the error-correction approach (ECM) with aims to examine whether an ECM does or does not have error correction.

$$
\begin{gathered}
\Delta y_{i t}=c_{i}+a_{0 i}\left(y_{i t-1}-b_{i} x_{i t-1}\right)+\sum_{j=1}^{K_{1 i}} a_{1 i j} \Delta y_{i t-j} \\
+\sum_{j=-K_{2 i}}^{K_{3 i}} a_{2 i j} \Delta x_{i t-j}+\mu_{i t}
\end{gathered}
$$

where $\alpha_{0 i}$ is the error correction or speed of adjustment term. The variables are not cointegrated if $\alpha_{0 i}=0$. In contrast, if $\alpha_{0 i}<0$, then there is an error correction term, which implies that the variables are cointegrated. Fully modified OLS (FMOLS) is regressed to determine the relationship between variables. Finally, proceed with shortrun causality tests using VAR Granger causality. The decision is whether to reject the null hypothesis of variable $X$ does not Granger cause variable $Y$ versus the alternative hypothesis of variable $X$ does Granger cause variable $Y$.

\section{RESULTS AND DISCUSSION}

Table 1 shows that the Breusch-Pagan LM test rejects the null hypothesis of no cross-sectional dependence for all the models. Thus, we can claim that there is a common factor affecting cross-sections in both countries.

Table 1. Breush-Pagan LM Test

\begin{tabular}{|c|c|c|}
\hline Model & $\begin{array}{c}\text { High-Income } \\
\text { Countries }\end{array}$ & $\begin{array}{c}\text { Low-Income } \\
\text { Countries }\end{array}$ \\
\hline 1 & $1335.648^{* * *}$ & $1789.821^{* * *}$ \\
\hline 2 & $2334.073^{* * *}$ & $1093.497^{* * *}$ \\
\hline 3 & $749.235^{* * *}$ & $611.981^{* * *}$ \\
\hline
\end{tabular}

Note: ${ }^{* * *}$ significant at 0.01 level, ${ }^{* *}$ significant at 0.05 level, *significant at 0.1 level (applicable to all subsequent tables)

Table II and III present the results of the panel unit root test using Pesaran (2003). At level, not all variables are stationary in both countries. However, all variables became stationary after first differencing. Thus, it can be said that they are integrated to order one, I(1).

Table 2. Panel Unit Root Test for High-Income Countries

\begin{tabular}{|l|l|l|}
\hline variables & without & with trend \\
\hline
\end{tabular}




\begin{tabular}{|c|c|c|}
\hline \multicolumn{2}{|l|}{ trend } & \\
\hline Level & & \\
\hline EC & $-2.865^{* * *}$ & $-2.827^{* * *}$ \\
\hline GDP & $-2.123^{* *}$ & -0.56 \\
\hline CO2 & -0.845 & -0.693 \\
\hline First difference & & \\
\hline EC & $-17.231^{* * *}$ & $-17.09^{* * *}$ \\
\hline GDP & $-13.749^{* * *}$ & $-13.57^{* * *}$ \\
\hline CO2 & $-17.122^{* * *}$ & $-16.95^{* * *}$ \\
\hline
\end{tabular}

Table 3. Panel Unit Root Test for Low-Income Countries

\begin{tabular}{|c|c|c|}
\hline variables & $\begin{array}{c}\text { without } \\
\text { trend }\end{array}$ & with trend \\
\hline Level & & \\
\hline EC & -0.109 & 1.651 \\
\hline GDP & $-3.095^{* * *}$ & $-2.344^{* *}$ \\
\hline CO2 & $-1.643^{* * *}$ & -0.976 \\
\hline First difference & & \\
\hline EC & $-15.696^{* * *}$ & $-15.42^{* * *}$ \\
\hline GDP & $-16.969^{* * *}$ & $-16.10^{* * *}$ \\
\hline CO2 & $-17.639^{* * *}$ & $-17.03^{* * *}$ \\
\hline
\end{tabular}

Westerlund (2007) introduced four panel cointegration test statistics (Gt, Ga, Pa and Pt) based on Error Correction Model. Referring to Table IV and V, using GDP as a dependent variable, the results strongly reject the null hypothesis of no cointegration. This means that GDP has a long-run relationship with $\mathrm{CO}_{2}$ and EC. Meanwhile, Table VI and VII show that $\mathrm{CO} 2$ has a long-run relationship with both EC and GDP in low-income countries. For the significantly cointegrated variables, FMOLS is then estimated. Table VIII shows that both GDP-EC has a positive stronger relationship than GDP-CO2 as the coefficient size is larger. However, GDP-CO2 has a negative relationship. Both relationships are strong as highly significant. As reported in Table IX, both variables have a strong positive significant relationship to $\mathrm{CO} 2$.

Table 4. Panel Cointegration Test for High-Income Countries

\begin{tabular}{|c|c|c|c|}
\hline \multicolumn{2}{|c|}{ Variables } & Gt & $\mathrm{Ga}$ \\
\cline { 3 - 4 } \multicolumn{2}{|c|}{} & \multicolumn{2}{c|}{ Z-value } \\
\hline $\mathrm{EC}$ & $\mathrm{CO}_{2}$ & -0.998 & -1.035 \\
\hline \multirow{2}{*}{$\mathrm{GDP}$} & $\mathrm{GDP}$ & 0.767 & 0.414 \\
\hline & $\mathrm{CO}_{2}$ & $-3.779^{* * *}$ & $-4.462^{* * *}$ \\
\hline & $\mathrm{EC}$ & $-3.57^{* * *}$ & $-3.902^{* *}$ \\
\hline
\end{tabular}

\begin{tabular}{|c|c|c|c|}
\hline $\mathrm{CO}_{2}$ & EC & -0.788 & -0.625 \\
\hline & GDP & 0.426 & 0.626 \\
\hline
\end{tabular}

Table 5. Panel Cointegration Test for High-Income Countries

\begin{tabular}{|c|c|c|c|}
\hline \multicolumn{2}{|c|}{ Variables } & $\mathrm{Pt}$ & $\mathrm{Pa}$ \\
\cline { 3 - 4 } \multicolumn{2}{|c|}{} & \multicolumn{2}{c|}{$\mathrm{Z}$-value } \\
\hline $\mathrm{EC}$ & $\mathrm{CO}_{2}$ & $-1.655^{* *}$ & $-2.214^{* *}$ \\
\hline & $\mathrm{GDP}$ & -0.788 & -1.061 \\
\hline $\mathrm{GDP}$ & $\mathrm{CO}_{2}$ & $-4.091^{* * *}$ & $-5.921^{* * *}$ \\
\hline & EC & $-3.967^{* * *}$ & $-5.737^{* * *}$ \\
\hline $\mathrm{CO}_{2}$ & EC & 1.373 & 0.228 \\
\hline & GDP & $-2.24^{* *}$ & $-2.559^{* * *}$ \\
\hline
\end{tabular}

Table 6. Panel Cointegration Test for Low Income Countries

\begin{tabular}{|c|c|c|c|}
\hline \multicolumn{2}{|c|}{ Variables } & Gt & Ga \\
\cline { 3 - 4 } \multicolumn{2}{|c|}{} & \multicolumn{2}{c|}{ Z-value } \\
\hline EC & $\mathrm{CO}_{2}$ & 3.928 & 1.473 \\
\hline & $\mathrm{GDP}$ & 3.017 & 0.945 \\
\hline $\mathrm{GDP}$ & $\mathrm{CO}_{2}$ & $-1.512^{*}$ & $-1.741^{* *}$ \\
\hline & $\mathrm{EC}$ & $-1.507^{*}$ & -1.087 \\
\hline $\mathrm{CO}_{2}$ & $\mathrm{EC}$ & $-1.511^{*}$ & -1.052 \\
\hline & GDP & $-1.731^{* *}$ & $-2.658^{* * *}$ \\
\hline
\end{tabular}

Table 7. Panel Cointegration Test for Low-Income Countries

\begin{tabular}{|c|c|c|c|}
\hline \multicolumn{2}{|c|}{ Variables } & $\mathrm{Pt}$ & $\mathrm{Pa}$ \\
\cline { 3 - 4 } \multicolumn{2}{|c|}{} & \multicolumn{2}{c|}{$\mathrm{Z}$-value } \\
\hline $\mathrm{EC}$ & $\mathrm{CO}_{2}$ & 2.848 & 1.423 \\
\hline & $\mathrm{GDP}$ & 1.415 & 0.085 \\
\hline $\mathrm{GDP}$ & $\mathrm{CO}_{2}$ & -0.672 & $-1.469^{*}$ \\
\hline & $\mathrm{EC}$ & -1.249 & $-1.848^{* *}$ \\
\hline $\mathrm{CO}_{2}$ & $\mathrm{EC}$ & $-4.426^{* * *}$ & $-4.525^{* * *}$ \\
\hline & GDP & $-4.719^{* * *}$ & $-5.267^{* * *}$ \\
\hline
\end{tabular}

Table 8. FMOLS estimates for High-Income Countries

\begin{tabular}{|r|c|c|c|}
\hline $\begin{array}{l}\text { Dependent } \\
\text { variable: } \\
\text { GDP }\end{array}$ & Coefficient & Std. Error & t-statistics \\
\hline $\mathrm{CO}_{2}$ & $-1.362^{* * *}$ & 0.251 & -5.429 \\
\hline EC & $3.721^{* * *}$ & 0.213 & 17.486 \\
\hline \multicolumn{2}{|r|}{ Adjusted R-squared } & \multicolumn{2}{|c|}{0.8950} \\
\hline
\end{tabular}


Table 9. FMOLS estimates for Low-Income Countries

\begin{tabular}{|c|c|c|c|}
\hline $\begin{array}{l}\text { Dependent } \\
\text { variable: } \\
\mathrm{CO} 2\end{array}$ & Coefficient & Std. Error & t-statistics \\
\hline $\mathrm{EC}$ & $0.576^{* * *}$ & 0.115 & 5.010 \\
\hline GDP & $0.269^{* * *}$ & 0.029 & 9.419 \\
\hline \multicolumn{2}{|c|}{ Adjusted R-squared } & \multicolumn{2}{|c|}{0.9222} \\
\hline
\end{tabular}

Table X reports the VAR Granger Causality to determine for short-run relationships. We can see that there is a bidirectional short-run relationship between EC and GDP in high-income countries. Contrary, the bidirectional shortrun relationship found in all pairs of variables except between $\mathrm{EC}$ and GDP in low-income countries.

TABLE X: Short-run Causality Test

\begin{tabular}{|c|c|c|}
\hline Null Hypothesis & $\begin{array}{c}\text { High- } \\
\text { Income } \\
\text { Countries }\end{array}$ & $\begin{array}{c}\text { Low- } \\
\text { Income } \\
\text { Countries }\end{array}$ \\
\hline & \multicolumn{2}{|c|}{ Chi-sq } \\
\hline $\mathrm{EC} \longmapsto \mathrm{CO}_{2}$ & $44.311^{* * *}$ & $7.259^{*}$ \\
\hline $\mathrm{GDP} \longrightarrow \mathrm{CO}_{2}$ & 13.171 & $9.209^{*}$ \\
\hline $\mathrm{CO}_{2} \longrightarrow \mathrm{EC}$ & $7 \cdot 383$ & $28.84^{* * *}$ \\
\hline GDP $\longrightarrow$ EC & $15.109^{*}$ & $11.039^{* *}$ \\
\hline COLCDP & 6.347 & 9.1.1** \\
\hline $\mathrm{EC} \nrightarrow \mathrm{GDP}$ & $15.632^{* *}$ & 2.807 \\
\hline
\end{tabular}

selected by the criterion LR, FPE, AIC, SC and HQ

\section{CONCLUSION}

This study investigated the long-run relationship and the short-run causality between three variables, namely energy consumption, $\mathrm{CO} 2$ and GDP in high and low-income countries from 1971-2014. Second generation panel unit root and cointegration test were conducted in the analysis. The objectives of the study are 1) to determine the short-run relationship (one-way or bidirectional) and 2) to reveal the long-run relationship between each pair of variables. The Breush-Pagan LM test indicates the presence of crosssectional dependence in all models. The series are integrated of order one, I (1) after doing the first differencing. Cointegration test in high-income countries indicates that energy growth has a long-run relationship with carbon dioxide and energy consumption. In low-income countries, carbon dioxide has a long-run relationship with energy consumption and economic growth. There is a bidirectional relationship between energy consumption and economic growth in high-income countries, but a one-way relationship in low-income countries in the short-run. Overall, it can be concluded that the three variables are related. This study provides a deeper understanding of the interactions between energy consumption, environmental degradation and economic growth in different income of countries to achieve sustainable development. 


\section{REFERENCES}

Ang, J.B. 2007, $\mathrm{CO} 2$ emissions, energy consumption, and output in France. Energy Policy 35, 4772-4778.

Apergis, N., \& Payne, J.E. 2009, Energy consumption and economic growth in Central

America: evidence from a panel cointegration and error correction model. Energy Economics 31: 211-21.

Bozkurt, C., \& Akan, Y. 2014, Economic Growth, CO2 Emissions and Energy Consumption: The Turkish Case. International Journal of Energy Economics and Policy 4: 484-494.

Dasgupta P.S., \& Heal G.M 1979, Economic theory and exhaustible resources: Cambridge University Press, Cambridge, UK.

Grossman, G.M., \& Krueger, A. B. 1991, Environmental impacts of the North American Free Trade Agreement. NBER. Working paper 3914.

Mercan, M., \& Karakaya, E. 2015, Energy Consumption, Economic Growth and Carbon Emission: Dynamic Panel Cointegration Analysis for Selected OECD Countries. Procedia Economics and Finance 23: 587-592.

Pala, A. 2016, Which Energy-Growth Hypothesis is Valid in OECD Countries? Evidence from Panel Granger Causality. International Journal of Energy Economics and Policy 6: 28-34.

Panayotou, T 1993, Empirical tests and policy analysis of environmental degradation at different stages of economic development. Working Paper WP238, Technology and Employment Programme, ILO, Geneva.

Ozturk, I. 2010, A literature survey on energy-growth nexus. Energy Policy 34: 340-349.

Ozturk, I., Aslan, A., \& Kalyoncu, H. 2010. Energy consumption and economic growth relationship: Evidence from panel data for low- and middle-income countries. Energy Policy 38: 4422-4428.

Pesaran, H. M. 2003, A Simple Panel Unit Root Test in the Presence of Cross Section Dependence. Mimeo, University of Southern California.

Solow, R. M. 1956, A contribution to the theory of economic growth. The MIT Press

Saatçi, M. V., \& Yasemin, D. 2011, Çevre Kirliliğive Ekonomik Büyüme İlişkisi: Çevresel Kuznets Eğrisinin Türk
Ekonomisil̇çin Yapısal Kırılmalı Eş-Bütünleşme Yöntemiyle Tahmini. Erciyes Üniversitesi İIBF Dergisi 37: 65-86.

Suocheng, L. Fei., Dong, X. L., Quanxi, L., \& Wangzhou, Y. 2011, Energy Consumption-Economic Growth Relationship and Carbon dioxide Emissions in China. The Journal of Energy Plicy 39: 568-574.

Wang, S.S., Zhou, D.Q., Zhou, P., \& Wang, Q.W. 2011, CO2 emissions, energy consumption and economic growth in China: A panel data analysis. Energy Policy 39: 568-574.

Westerlund, J., 2007, Testing for error correction in panel data. Oxford Bulletin of Economics and Statistics 69: 709748.

Yin, J., \& Zheng, M. Chen, J. 2015, The effects of environmental regulation and technical progress on $\mathrm{CO} 2$ Kuznets curve: an evidence from China, Energy Policy 77: 97

Zaman, K. \& Moemen, M. 2017, Energy consumption, carbon dioxide emissions and economic development: Evaluating alternative and plausible environmental hypothesis for sustainable growth. Renewable and Sustainable Energy Reviews 74:1119 1130. 